Cuestiones de filosofía

ISSN: 0123-5095

Vol. 1 - No. 17

Año 2015

pp. $239-257$

\title{
EL VIDEOJUEGO: DEL SIMULACRO A LA IMAGEN-PENSAMIENTO*
}

\section{The Videogame: From Simulacrum to the Image-Thought}

\author{
José Fernando-Gómez \\ gomezgo.jose@urosario.edu.co \\ Universidad del Rosario (Colombia)
}

Fecha de recepción: 11/11/ 2014

Fecha de evaluación: 24/02/2015

Fecha de aprobación: 15/09/2015

Entonces el cine puede llamarse cine-verdad, tanto más cuanto que habrá destruido todo modelo de lo verdadero para hacerse creador, productor de verdad: no será un cine de la verdad, sino la verdad del cine.

Gilles Deleuze

\section{Resumen}

El artículo describe y problematiza las relaciones existentes entre la imagen del videojuego y la imagen del cine, planteada por Gilles Deleuze como imagenpensamiento. En la primera parte, mediante la descripción de las imágenes del videojuego y su comparación con las imágenes del cine, que describe Deleuze, se pretende trazar una hipérbole que permita ver las imágenes del videojuego como potencialmente más complejas que las presentadas por el cine. La imagen del

* A lo largo de este artículo se hará referencia a varios videojuegos; la mayoría de ellos pueden ser visualizados en el portal de video YouTube. Invitamos al lector a acercarse al menos a los tres más conocidos y a buscar allí la referencia directa de lo que aquí se diga. Grand Theft Auto [https://www.youtube.com/watch?v=F9tni2Z-T0w]

Heavy Rain [https://www.youtube.com/watch?v=UMA_fal8FcM]

Beyond two Souls [https://www.youtube.com/watch?v=UJfko7lqqE0] 
videojuego, potenciada por el concepto de simulacro, complejiza la forma como el ser humano establece ciertos vínculos con la realidad y con el concepto mismo de realidad. La segunda parte se aborda mediante los conceptos de simulacro de Baudrillard y Deleuze, para llegar al simulacro pensado en clave de interactividad, desde donde es plausible concluir que las imágenes del videojuego tienen también la potencia de la imagen-pensamiento.

Palabras clave: Videojuego, Imagen-Pensamiento, Simulacro, Interactividad, Cine.

\begin{abstract}
This paper describes and problematizes the relationship between the image of the video game and the image film posed by Gilles Deleuze as thinking-image. In the first part, by describing the images of the video game and its comparison with the images of cinema that Deleuze describes, it is intended to draw a hyperbole that can view pictures of the video game as potentially more complex than those presented by the film. The image of the video game, powered by the concept of simulacrum, complicates how human beings establish some links with reality and with the concept of reality. The second part is addressed through the simulacrum concepts of Baudrillard and Deleuze, in order to reach the simulacrum thought in key interactivity, where it is plausible to conclude that the images of the video game also have the power of the thinking-image.
\end{abstract}

Key words: Videogame, Thinking-Image, Simulacrum, Interactivity, Cinema.

\title{
1. INTRODUCCIÓN: IMAGEN, PENSAMIENTO Y SIMULACRO
}

Cuando Gilles Deleuze escribió sus estudios sobre cine tenía en mente una empresa filosófica particular bastante concreta: crear conceptos a partir de las imágenes cinematográficas (Deleuze y Guattari 1993, 8). Pero contrario a lo que pudiera pensarse de un filósofo, Deleuze no se propuso subsumir la imagen en las categorías de la filosofía, por el contrario, empezó negando esa primacía para hacer que el pensamiento y la imagen pudieran entenderse en términos simétricos, esto es, hacer que uno y otra pudieran referirse entre sí para analizar cómo se afectaban en su especificidad propia, afectación después de la cual ninguno de los dos volvió a ser lo que era (Cárdenas, 2011, pp. 244-246). 
En palabras más sencillas, el objetivo de Deleuze era ver, mediante el diálogo de resonancias entre pensamiento e imagen, qué tienen para decir y enseñarse mutuamente, $y$, particularmente, qué tiene que decir la imagen del cine sobre el pensamiento. La imagen se ofrece, entonces, como una vitrina para observar los mecanismos propios del pensamiento, su estructura. El cine de Eisenstein, y el montaje de oposición de contrarios (luz/oscuridad; pobres/ricos, etc.), por ejemplo, pone en evidencia las particularidades del pensamiento dialectico. De ese modo particular, las artes pueden actuar sobre el pensamiento, así como este puede actuar sobre ellas. Es con base en esta relación recíproca entre la imagen y el pensamiento que este artículo cobra sentido, ya no viendo qué puede decir la imagen del cine al pensamiento, sino qué puede decir una imagen nueva, como la del videojuego, en el ámbito del pensamiento.

Una primera mirada hace pensar que el videojuego tiene similitudes con el cine, con sus métodos de producción y sus ideas estéticas, así como diferencias con él, pues el cine debe entenderse como una re-producción de lo real, y el videojuego como la realización gráfica de un modelo. Otra diferencia es que las resonancias entre imágenes y pensamiento, en el caso del videojuego, están fuertemente ligadas al concepto de simulacro y a su potencia de simulación. La inclusión de un jugador que interviene activamente en la imagen, junto con la potencia simulativa de esta, abren el espacio del juego para repensar la realidad en términos del simulacro. En lo que sigue, (i) se empezará por trazar el parecido de los dos regímenes de imágenes (cine/videojuego), en los términos analíticos que el mismo Deleuze propone; luego, (ii) se plantearán los desafíos que el nuevo régimen de imágenes conlleva para la relación imagen/pensamiento en términos de simulacro e interactividad, y, finalmente, (iii) se harán algunas consideraciones.

\section{DOS REGÍMENES DE IMÁGENES}

Una chica sin recuerdos está sentada en la oficina del sheriff en un pueblo norteamericano en medio de la nada; el sheriff la interroga, curioso por saber qué le ha sucedido o cómo ha llegado allí; los recuerdos de la mujer vienen y van: luces en medio del bosque, perros ladrando en la oscuridad, un jadeo asfixiante mientras se le ve corriendo. De vuelta en la oficina del sheriff, un escuadrón del SWAT entra sin mayor aviso; la están buscando a ella, que permanece inmóvil en la silla. El sheriff sale de su oficina, y luego de que le preguntan por "la mujer que recogió" les indica dónde está. La siguiente escena muestra un coche que llega al lugar, y un hombre en traje que entra a la comisaria y la encuentra totalmente destruida: los cuerpos del 
equipo SWAT están regados por el suelo junto con muchos escombros, y no hay rastros de la mujer; entonces, la cámara se aleja para dejar ver en un plano general a un sheriff aterrorizado que se mantiene en pie en la mitad de la sala destruida.

¿Estamos aquí ante la escena inicial de una película de acción?, ¿es acaso el último estreno de Hollywood? En un principio podría parecer así, sin embargo, lo descrito corresponde a la secuencia inicial del videojuego Beyond: twosouls. Lejos estamos ya de pac-man escapando de los fantasmas mientras se alimentaba a través de los niveles laberínticos, o de Mario Bros saltando de tubería en tubería en busca de su princesa de 8 bits. En primer lugar, habrá que decir que esta cercanía narrativa no siempre ha existido y que solo hasta ahora, en los últimos años, las fronteras entre la imagen cinematográfica y la imagen cinemática del videojuego se están haciendo cada vez más difusas. Tanes así que el visionado de las secuencias de juego a través de portales web como YouTube es similar a como se vería un seriado televisivo o una película, lo que antes era imposible, pues los juegos estaban diseñados para dar al usuario un entretenimiento más lúdico que estético y contemplativo. Hoy, sin embargo, se puede obtener del visionado de un videojuego una experiencia muy similar a la que se tiene cuando se ve una película, gracias a que el cine y el videojuego actual comparten el uso de la composición de la imagen y el montaje.

Los videojuegos, como el cine, traen ante el espectador determinadas imágenesmovimiento cuidadosamente compuestas, mediante las cuales agencian bloques de sensación que interpelan al espectador, todas ellas unificadas mediante un montaje particular de cortes móviles de espacio-tiempo; sin embargo, lo que hoy es tendencia mundial no siempre fue así. Las cinemáticas del videojuego, del mismo modo que las imágenes del cine empezaron siendo cortes inmóviles, pues las técnicas más rudimentarias de animación apenas permitían simular el movimiento más básico. En consecuencia, las primeras imágenes del videojuego eran cercanas a la toma fija y el plano inmóvil; la mayoría de ellas consistía en una silueta del personaje que posteriormente era animada para simular movimientos de habla que venían acompañados de texto, mediante los cuales el jugador podía enterarse de la historia. Un clásico ejemplo de este tipo de imagen está presente en la saga de juegos Mega Man, producida por Capcom; en ella se presentaba una imagen totalmente inmóvil (silueta) a la que luego se agregaba tiempo abstracto (animación); el tiempo apenas se insinuaba en estas imágenes de manera tangencial.

Así, pues, al igual que el cine, solo un avance tecnológico le permitiría al videojuego acceder a todas sus potencialidades al darle acceso a la presentación de genuinas 
imágenes-movimiento. Enestas imágenes, al contrario que con los cortes inmóviles, el movimiento ya no proviene de una añadidura externa que hace que la imagen inmóvil imite el movimiento, sino que, por el contrario, este pertenece a la imagen como dato inmediato (Deleuze, 1985a, p. 15); es decir,que el movimiento está ya presente en el corte. Este avance se dio en el cine gracias a la aparición de la cámara móvil, que permitió incluir este movimiento dentro del corte. Del lado del videojuego este avance se dio gracias a que la animación empezó a realizarse en tres dimensiones, lo que permitió que la imagen adquiriera profundidad de campo y pudiera empezar a ser pensada en términos de composición. Lo mismo sucedió con la imagen cinematográfica que en su momento había permanecido congelada en el plano general.

Fue gracias al medio tecnológico quela composición creativa de las imágenes tanto del cine como del videojuego pudieron obtener el estatuto de cortes móviles. Tanto en el cine como en el videojuego se da un paso de la imagen como instante privilegiado (al que se le agrega tiempo abstracto para conseguir movimiento) hacia la imagen como "momento cualquiera", lo que significa que la imagen en movimiento es comprendida ya no como una fotografía que se une a otras para generar un movimiento, sino como un corte tomado de la duración del tiempo que por sí mismo da la impresión de continuidad (Deleuze, 1985a, p. 18). En ellas ya no puede encontrarse una silueta definida, sino que, por el contrario, la imagen está en continua transformación; tal es el caso de las imágenes en Silent Hill 2, videojuego producido por Konami, que son de las primeras en usar este tipo de animación que ya tiene en cuenta también la composición de la imagen y la profundidad de campo. Al contrario que en Mega Man y otros juegos por el estilo, donde una silueta era animada luego mediante la inclusión de movimiento, en Silent Hill 2 las imágenes están ya constituidas ellas mismas como cortes móviles; en ellas ya hay movimiento.

Ahora bien, con la configuración de la imagen como corte móvil, las imágenes del videojuego se constituyen como potencialmente equivalentes a las imágenes del cine, por lo que debería ser posible hablar de la imagen-acción en los videojuegos más comunes; del mismo modo que de la imagen-tiempo en aquellos cuya narrativa e historia son más complejas. Sin embargo, existe también una diferencia fundamental entre el cine y los videojuegos, que será retomada más adelante, y se trata de la inclusión activa del espectador como jugador, actitud activa que no se contempla en el cine, con lo que entra en escena el factor lúdico del videojuego, pues la presencia y la acción del jugador se hacen vitales en tanto el juego debe ser jugado para que la historia se desarrolle. 


\section{EL VIDEOJUEGO Y LA IMAGEN ACCIÓN: GTA V}

Una vez puestas en relieve las similitudes y diferencias entre el cine y el videojuego, quisiera ver cómo operan los conceptos de Deleuze sobre un ejemplo concreto. En este apartado se hará referencia a un juego que se considera puede ser leído en clave de imagen-acción: se trata de $G T A V^{1}$. Empecemos por retomar la definición de Deleuze sobre imagen-acción, que no es otra cosa que la síntesis de perceptos, afectos y pulsiones que derivan en acciones que las encarnan (Deleuze, 1985a, pp. 203-204). Lo vital de esta imagen es la relación entre las fuerzas y un centro de indeterminación, de modo que la imagen-acción está siempre atada a la reacción en las situaciones. El jugador y el personaje al que da vida deben reaccionar a situaciones límite implícitas en imágenes sensomotrices en las que el espectador/jugador es capaz de participar. A la identificación propia del cine (Deleuze, 1985b, p. 13) se suma, en el caso del juego, la interacción motriz con el mando que ratifica a cada momento esa relación.

Tal es el caso de GTA $V$, donde las acciones de los protagonistas están motivadas por pulsiones y situaciones límite que los empujan a actuar. El juego comienza con Michael De Santa traicionando a sus amigos durante un asalto de banco en el que con ayuda del FIB finge su muerte; pero tiempo después (luego de llevar una vida relativamente normal) descubre que su esposa lo engaña; la revelación lo lleva a ser dominado por la pulsión de los celos y, como consecuencia, termina destruyendo la casa de un poderoso narcotraficante, que le exige pagar la reconstrucción. La situación límite de pagar la deuda o ser asesinado junto con su familia obliga a Michael a volver a su vida de ladrón, lo que irá desencadenando una gran cadena de eventos que vuelven a estar relacionados con su pasado y con las decisiones que ha tomado. Los otros dos protagonistas, Franklin y Trevor, se enfrentan también al influjo de sus pasiones y pulsiones que de igual modo los ponen en situaciones límite.

Las acciones y el desarrollo de la historia de GTA Vestán condicionados siempre por la reacción a un acontecimiento inesperado, acciones que además son asumidas y llevadas a cabo por el jugador/espectador que debe vérselas con imágenes percepción, afección y pulsión con las que convive y que en últimas le exigen adquirir

1 Siglas para Grand Theft Auto V. para mayor información sobre la saga ver :http:// www.rockstargames.com/grandtheftauto/ o https://en.wikipedia.org/wiki/ Grand_Theft_Auto_(series) 
una nueva manera de ser o cambiar sus maneras de ser de acuerdo con las exigencias del medio y la situación. Tal es también el caso de Franklin, quien debe tomar una decisión fundamental y adaptarse a la situación cuando le piden matar a sus dos amigos y compañeros a cambio de conservar la vida; duelo de fuerzas con el medio, con los otros y consigo mismo; todo ello de manera simultánea, pues, como afirma Deleuze del cine, cada situación está tirando de otras líneas de acción (1985a, pp. 204-219).

La imagen-acción toma entonces la forma del realismo, en tanto las acciones están dadas por una suerte de conductismo; pero es un conductismo mucho más complejo de lo que parece, pues considera factores internos (Deleuze, 1985a, p. 224). Así, aquello que debe aparecer en el exterior es lo mismo que sucede en el interior del personaje, en el cruce de la situación que lo impregna y de la acción que él va a hacer detonar. Los afectos y las pulsiones que poseen a Trevor cuando descubre que Michael lo engañó en el pasado se reflejan de manera cristalina en sus acciones y sus gestos. Del mismo modo, y para mantener el realismo instaurado, se configuran también relaciones emoción-objeto en las que el objeto es captado en toda su virtualidad al mismo tiempo que las emociones actualizadas. Tal es el caso de la relación fetichista que sostiene Trevor con un oso de peluche que se ve envuelto en un sinfín de situaciones hasta ser sodomizado por Trevor en un momento de locura.

La imagen-acción se presenta entonces como un discurso realista y verídico en tanto aspira a la verdad aun en la ficción. Así, aunque en su estructura puede incluir tambien recuerdos, sueños y delirios, en su visualizacion el sistema sensorio motor se despliega adecuadamente (Deleuze, 1985b, p. 173), es decir, que los diferentes estados de percepcion no resultan indiscernibles. Las imágenes que se presentan se mantienen claras y diferenciadas; se sabe bien qué es un sueño y qué es un recuerdo. De modo que, aunque consituyen un régimen de imágenes complejo, las rupturas narrativas, como elipsis y espirales, operan como representaciones indirectas del tiempo. No son imágenes-tiempo, ya que la imagen emana de la acción, depende del movimiento y se deduce del espacio, por loque no importa cuán dislocado esté el tiempo siempre volvemos al principio del tiempo cronológico (Deleuze, 1985b, pp. 173-174).

\section{El VIDEOJUEgo Y LA IMAGEN-TIEMPO: DE HEAVY RAIN A BEYOND TWO SOULS}

Más cercanos a la imagen-tiempo están los dos títulos de QuanticDreams, en los que deliberadamente se ha reducido la interacción a favor del registro y la 
presentación de situaciones puramente ópticas y sonoras. En el 2010, Heavy Rain tuvo su debut en las consolas y llegó para revolucionar las narrativas del videojuego. Si las imágenes-acción de GTA V parecen estar cerca de la narrativa del cine tradicional, en Heavy Rain no hay duda de que nos encontramos en un punto de indiferenciación entre la imagen-acción y la imagen-tiempo.

Heavy Rain comienza con un prólogo que tiene lugar en la casa de Ethan Mars, un arquitecto de éxito que tiene la vida perfecta. En el prólogo, que dura unos 35 minutos, se nos muestra la cotidianidad de Ethan, desde levantarse y ducharse hasta salir a jugar con los niños en el jardín. Esta primera parte está constituida por imágenes-afección, esto es, un sinfín de primeros planos que detallan los estados emocionales de los personajes. En esta primera parte se logra una primera presentación del tiempo cristalizado ${ }^{2}$, en tanto las acciones están muy restringidas y corresponden a lo cotidiano. El paroxismo del prólogo logra hacer que el jugador se abandone, junto con el personaje, a bloques de inacción en los que se entrega a una presentación-visual y sonora-pura del tiempo (Deleuze, 1985b, p. 14).

Es tan pura la presentación que para muchos videojugadores puede resultar insoportable, precisamente porque ante la presentación de estas imágenes y sonidos puros, los personajes, que solían reaccionar ante las situaciones (lo hacían incluso cuando, a causa de los accidentes, se veían reducidos a la impotencia) ahora están condenados a la inacción, pues por más que se muevan, corran y se agiten, la situación en que se encuentran desborda por todas partes su capacidad motriz, de modo que más que reaccionar frente $a$, registran la pura imagen (Deleuze, 1985b, p. 13). El hijo mayor de Ethan se ha perdido en una multitud. Ethan se entrega a la acción más pura dada por una situación límite, pero, incluso en la acción, el tiempo se presenta casi detenido, pues aunque la adrenalina y la tensión crecen por la pérdida del hijo mayor en el centro comercial, los movimientos de Ethan son lentos y, además, están siendo retrasados por una muchedumbre que le impide llegar a Jason, quien luego de una persecución en ralenti finalmente es arrollado por un coche.

Contrario a la imagen-acción, aquí hay un derrumbamiento de los esquemas sensoriomotores (Deleuze, 1985b, págs. 175-176); la imagen no está subordinada al movimiento todo el tiempo, sino que, por el contrario, tiende a cero, lo que

2 El tiempo cristalizado corresponde a un tiempo escindido que conserva todo el pasado y hace pasar todo el presente; se ve en el cristal la perpetua fundación del tiempo, el tiempo no cronológico (Deleuze, 1985b, p. 114). 
desemboca en una crisis de la acción. Más aún, en Heavy Rain la imagen-tiempo termina por distorsionar la imagen-acción. En la deriva del tiempo presentado, los movimientos que produce son necesariamente falsos, pues responden a un tiempo en el que tanto jugador como personaje están incapacitados para actuar, e incluso se resisten a ver.

Sin embargo, Heavy Rain está aún a medio camino. La narrativa cristalina solo llega a su clímax con Beyond: twosouls, juego que desarrolla la historia de Jodie Holmes, una joven con dones sobrenaturales, capaz de comunicarse con espíritus y que vive atada a uno desde que tiene memoria, por lo cual ha sido objeto de estudios del gobierno americano desde pequeña. El juego comienza con una Jodie que ha escapado de sus responsabilidades con el gobierno y, mientras huye, reconstruye sus recuerdos. Las imágenes-acción de sus escapes de las agencias del gobierno la llevan a situaciones límite que se intercalan con la exposición de imágenes ópticas y visuales puras del recuerdo y sueño, en ocasiones indiscernibles entre sí, las cuales registran y presentan el tiempo mientras que exponen la vida de la protagonista en su inacción. El jugador tiene que entregarse a la inacción mucho más radicalmente que en Heavy Rain, pues son muchas más las horas dedicadas al desmarañamiento de los recuerdos/pesadillas de Jodie que a la acción de escapar.

El montaje en este caso es mucho más complejo, pues no solo salta en una rapsodia de recuerdos y pesadillas, sino que no hay una sola referencia temporal o espacial que garantice de una u otra forma un principio cronológico. Solo la contextura de la protagonista brinda pistas sobre su edad, pero no deja de ser una especulación, pues incluso en las secuencias en las que es una niña no se tiene claridad de cuál precede a la anterior. En la intrincada red de flashbacks que organizan estos bloques de imágenes, el jugador no puede más que sumergirse en el todo, en el bloque de sensaciones puro propio de la imagen cristal, abandonando la pretensión de reordenar cronológicamente el desarrollo de la historia. En lugar de buscar el sentido, aquí se invita al jugador a dejarse afectar por el sin sentido de lo que ve.

\section{VideOJUEgo Y SIMULACRO}

Ahora bien, aunque el videojuego presenta la división analítica que Deleuze realiza de las imágenes cinematográficas, tiene también diferencias, sobre todo en el campo de la producción y en las formas de interacción. Esas diferencias se profundizan en la relación que uno y otro tienen con el simulacro y con la imagen-pensamiento. Así, pues, habrá que preguntarse qué relación establece el videojuego con el simulacro. 
Para ello es conveniente revisitar algunos conceptos, suponiendo que las imágenes del videojuego son equivalentes a las imágenes del cine. Para el cine, la aparición de imágenes ópticas y sonoras puras puso de relieve la complejidad temporal; en el videojuego esta complejidad se potencia por la interactividad. Este nuevo factor en la ecuación plantea nuevos retos para el pensamiento, especialmente alrededor del problema ontológico de la realidad y la verdad de las imágenes. La complejización del espectro imagen+interacción hace necesario repensar los alcances del concepto de simulacro. El viedojuego no solamente se constituye como simulacro, sino que, con fines distintos a los del cine, su vocación y su empresa es constituirse como el mejor simulacro posible.

Atendamos primero a la necesidad de esclarecer qué hace de los videojuegos parte de un régimen de simulacros, o, mejor, empecemos por aclarar qué entendemos por simulacro. La idea misma de simulacro debe rastrearse hasta la teoría platónica de las ideas, a su vocación radicalmente eidética, es decir, apegada a una idea modélica de identidad que permite tener un criterio de selección estricto entre el modelo y la copia. Siendo la 'cosa' real una copia del modelo, toda copia de la cosa será considerada un simulacro que accede a la idea a través del engaño artístico o la falsa semejanza.

¿Qué tiene que ver todo esto con la imagen del videojuego? La respuesta parece estar en la distancia radical que estas imágenes instauran entre lo que es y lo que parece ser (lo real y lo simulado). Las imágenes representan en ese sentido un desafío a la hora de mantener ese sentido estable de identidad que parece garantizar la reproducción cinematográfica; pero no tanto por la calidad de la reproducción, sino por la credibilidad que les otorga el jugador. Las imágenes del juego ponen, mediante la interactividad, a su espectador en una posición compleja: la sincronía que unas y otros pueden establecer es tan fuerte que, en algunos casos, el jugador llega a asumir que las imágenes del juego son más reales que lo real mismo. Esta capacidad de poner en cuestión lo real es propia del simulacro, que con su aparición subvierte esa fijeza de la identidad eidética.

El juego se configura como espacio de simulación por excelencia, como el lugar donde el recrear la realidad se vuelve una exigencia categórica; aquíla similitud con lo real es cada vez más radicalmente puesta a prueba, y el éxito de un videojuego radica precisamente en eso; sin embargo, la voluntad de simulación puede resultar problemática. La discrepancia entre las concepciones que Deleuze y Baudrillard tienen del simulacro puede, seguramente, ayudar a comprender el problema y sus 
implicaciones en la concepción ontológica de la realidad, dado que, a mi juicio, la discrepancia entre estas dos concepciones es precisamente producto de las variaciones fundamentales que las imágenes que proliferan ante nosotros hicieron posible.

Para Baudrillard, el mundo que aparece ante nosotros, la realidad, así como las imágenes que proliferan frente a nuestros ojos, no tiene equivalente ninguno, no pueden canjearse; en sus propias palabras: "no existe un equivalente para el mundo. En eso consiste precisamente su definición, o su indefinición" (2000, p. 11); esto implica que en su concepción ontológica lo real y lo verdadero son arbitrarios, imposturas que solo existen como formas de ordenar un caos de indiferenciación originario, una incertidumbre sobre el mundo y las cosas que lo componen, pues ninguna de estas cosas tienen sentido fuera de sí mismas, no se pueden canjear con nada (p. 12). Como resultado, para Baudrillard la esfera de lo real no puede ser canjeada con la esfera del signo, pues para que un intercambio así se dé debe existir un principio de equilibrio que sirva de mediador entre las partes, en este caso entre lo real y el signo; sin embargo, este principio ya no es posible formularlo, las normas bajo las cuales los intercambios deben darse han dejado de funcionar y se está de frente al desorden especulativo.

Aparece entonces la ilusión como elemento fundamental; la ilusión de que este intercambio es posible y que es llevado a cabo de modo que tras la ilusión de un intercambio de algo se esconde de manera evidente un intercambio de la nada, de modo que indefectiblemente cuando la realidad hace frente a su signo, a aquello por lo que es canjeada, que es la virtualidad, queda imposibilitada para canjearse nunca más, pues la proliferación de lo virtual hace que el principio de equilibrio se desmorone, que las normas y los principios de canje ya no funcionen adecuadamente (Baudrillard, 2000, pp. 13-15). De modo que solo queda en el universo, en todos los terrenos posibles, la incertidumbre radical, y esta debe constituirse como regla de juego, como única norma para entender el mundo.

El problema fundamental de la aparición de esta incertidumbre radical yace, para Baudrillard, en que todo aquello que junto con su aparición debería morir ha olvidado hacerlo; así, la incertidumbre radical no es la norma guiadora. Aunque nos movemos en un mundo de incertidumbres, avanzamos a través de él armados de certidumbres, pero no cargamos sus cadáveres (en palabras del mismo Baudrillard: "si tal cosa como el cadáver de lo real existe, aún no lo hemos encontrado"), cargamos con todos sus ritos, normas y certezas. Por lo cual, aun viviendo en este mundo de indiferenciación 
y de incertidumbre, el pensamiento $\mathrm{y}$, en general, todos los sistemas humanos se esfuerzan en escapar de esta incertidumbre, por hacer del intercambio imposible posible, encontrando las equivalencias de todas las cosas (Baudrillard, 2000, pp. 19-21), para que de esa manera la incertidumbre se despeje y sea posible volver a la certeza. Baudrillard ha sido muy claro al decir que todas las empresas que se han llevado a cabo para lograr este cometido han fallado de manera rotunda y se han chocado de nuevo con la barrera hasta ahora infranqueable del intercambio imposible. Sin embargo, ve en la aparición de lo virtual, de la simulación, en últimas del simulacro, la última vanguardia de ese deseo de superar la incertidumbre y reificar la certidumbre mediante la instauración de un equivalente del mundo, de lo real, aquello por lo cual finalmente lo real puede canjearse (Baudrillard, 2000, pp. 21-22).

Aquello que resulta del canje de lo real y lo virtual se constituye entonces comorealidad virtual en todas sus formas; una realidad que es más real que lo real, su equivalencia total, la solución final (Baudrillard, 2000, pp. 21-22). Ahora bien, la aparición del simulacro como último esfuerzo por dar un sentido y un orden al mundo, por poder canjearlo con su otro, hace que el simulacro y la simulación de lo real proliferen en su negatividad, aunque sigan siendo percibidos como una ilusión radical frente a la incertidumbre fundamental (Baudrillard, 1978, p. 47). Baudrillard utiliza un ejemplo de la biología: gracias al proceso de apoptosis, las células tienen un número limitado de divisiones para después morir; sin embargo, cuando se introduce abruptamente alguna perturbación en ese orden, el proceso de apoptosis falla, y la célula olvida cómo morir, por lo que procede a clonarse a sí misma hasta formar un tumor cancerígeno que casi siempre termina por dar la muerte al sujeto. De forma similar, al introducir en la ecuación de lo real algo con lo qué intercambiarse, se introduce entonces ese fallo que hace de la realidad algo inútil (Baudrillard, 2000, p. 47). La realidad ahora puede intercambiarse con su doble; lo real empieza a operar como una célula que ha olvidado morir. Más aún, todo aquello que compone la realidad, las imágenes que la constituyen, aunque están muertas, han olvidado cómo morir, subsisten en su virtualidad como extremidades fantasmas de un miembro amputado (Baudrillard, 2000, pp. 48-50).

En ese sentido, el videojuego como simulacro es para Baudrillard otra forma de aniquilación de lo real, y su sustitución por su doble operativo, y por eso mismo renuncia a esa certidumbre que se instala en el lugar de la incertidumbre fundamental. Para Baudrillard, los simuladores virtuales de la vida humana que los videojuegos ofrecen son un mecanismo que, ante la incertidumbre fundamental de lo real, impone una certidumbre que se constituye como su doble efectivo. Cabe aquí el ejemplo de 
Sims City, un simulador que permite dar vida a una ciudad con todos sus problemas sociales y políticos y donde, al resolverlos, la utopía pueda verse consumada. En el mundo de la realidad virtual, en el que Baudrillard cree nos instalamos de manera pulsional para evitar la incertidumbre de lo real mismo, la utopía está consumada gracias a esa ilusión, a ese reflejo de lo real que ha empezado a tomar su lugar.

A Deleuze, por el contrario, la proliferación de simulacros le parece positiva, en tanto que gracias a ellos se produce la aparición de distribuciones nómadas y de cierta imposibilidad de orden, de jerarquía; así, termina por afirmar los efectos de la producción de simulacros (Deleuze, 2005, pp. 264). Deleuze encuentra en esa potencia caótica uno de los orígenes de la efectividad de la imagen. Mientras en Baudrillard el simulacro tiene una fuerza negativa, negación de lo real y consumación de la ilusión de certeza, en Deleuze opera en un sentido positivo. Deleuze también encuentra en lo real algo lleno de potencias de incertidumbre y de indiferenciación, sin embargo, ve el simulacro no como una forma de retorno a la seguridad de un estado previo, garantía de la permanencia de las certezas, sino todo lo contrario, como el potenciador de esta diferenciación fundamental.

Es gracias al simulacro que se abre el camino a nuevas experiencias mediante una inversión de la representación. La semejanza del simulacro, que en Baudrillard ocupa el lugar del doble perverso, es ahora proyectada y retroyectada, "[el simulacro] no presupone lo mismo y lo semejante, sino que, por el contrario, constituye el único mismo de lo que difiere, única semejanza de lo desemparejado" (Deleuze, 2005, p. 266). En Baudrillard, la presencia del simulacro como reemplazo efectivo de lo real empobrece la experiencia del sujeto (en tanto que el simulacro resulta no ser nada más que una ficción, una ficción que se prefiere a lo real, pues le salva de su monstruosidad, de la monstruosidad de la incertidumbre), interponiéndose entre lo real y su percepción, ocupando su lugar. En Deleuze, por el contrario, el simulacro es en sí mismo cada vez una realidad nueva que se despliega y otorga nuevas posibilidades de pensamiento, de sensación, de experimentación. Así, mientras Baudrillard sigue condenando la huida del simulacro a la seguridad de la representación, en Deleuze el simulacro no tiene que ver ya con la idea de representación en sentido estricto. Las imágenes que el simulacro ofrece ya no son más representaciones, se han liberado de la carga representativa para adoptar una nueva fuerza expresiva.

En síntesis, Deleuze y Baudrillard coinciden en otorgar al simulacro la capacidad de expresar la multiplicidad e incertidumbre del mundo y de las imágenes que lo 
constituyen; para ambos, su aparición significa la confirmación de esas incertidumbres sobre cómo se presenta lo real ante nosotros, pero difieren en el rol ontológico que cumple el simulacro en el proceso de entendimiento del mundo. Para Baudrillard, la simulación es una operación de retorno a un momento anterior mucho más cómodo (el de las certezas y las normas funcionales) que tiene como consecuencia la aniquilación de lo real, y que termina por transformarlo en un cadáver viviente que ha olvidado cómo morir y se mantiene como un fantasma degradado, inoperante, en tanto se está confinado a la simulación. En Deleuze, la entrega a la ilusión y a la certeza no está dada por la aparición y proliferación del simulacro; por el contrario, es su potencia ontológica la que afirma el carácter indiferenciado e incierto de lo real, en tanto puede proliferar de manera ilimitada. Aquí el simulacro es el abandono de la pulsión de retorno y la aceptación de la condición múltiple y diferenciada de lo real.

Volvamos, entonces, luego de este breve repaso de las concepciones de simulacro, a las imágenes del videojuego. Es hora de preguntarnos qué ofrecen las imágenes del videojuego para enriquecer la discusión sobre el simulacro. Una primera respuesta, un tanto ambigua, diría que las imágenes del videojuego problematizan aspectos fundamentales de las dos concepciones de simulacro que hemos descrito anteriormente. Desde la perspectiva de Baudrillard, estamos asistiendo quizá a la consumación de su mayor temor, una realidad virtual por la que lo real puede intercambiarse de manera efectiva, haciendo que quienes se exponen a estas imágenes, que son ahora interactivas, puedan reemplazar lo real con ellas y someterse a la ilusión de certeza que estas imágenes le ofrecen. Del otro lado, desde la perspectiva deleuziana, la imagen del videojuego se constituye como otro campo de ese real incierto y diferenciado que pone de nuevo a rodar el pensamiento, que amplía el espectro de lo real y lo hace más complejo; de modo que permite, mediante la apreciación y apropiación de esas imágenes-simulacro, comprender aspectos de ese real que de otra forma pasarían inadvertidos ante nuestra mirada.

De aquí se desprende una segunda respuesta, enfocada ahora en la cuestión de si la particularidad material de las imágenes del videojuego, creada en función de la interactividad, permite nuevos desarrollos alrededor del concepto de simulacro. La respuesta que quiere dar este artículo es que sí, pues de una u otra forma el simulacro, como lo hemos descrito, no contempla esa nueva materialidad en la que vendría a proliferar y a germinar la radicalización del simulacro, en tanto que la imagen del videojuego esta aún más alejada, es aún más simulativa que la imagen del cine, y esto es así gracias a la aparición de esta interactividad. De modo que el simulacro, 
al menos el que prolifera desde las imágenes-movimiento, debe ser repensado, ya no solo bajo la luz de la imagen del cine, sino también desde la imagen-interactiva del videojuego. La razón es que en ella el simulacro opera de manera mucho más abstracta, en tanto la imagen interactiva del videojuego, como la del cine, no debe ser entendida como mimética y representativa; por el contrario, en ella debe intuirse la aparición de una nueva realidad que le es propia. De cierta manera, las concepciones de simulacro presentadas deberían, quizá, buscar un punto de convergencia en esta nueva forma de simulacro que tiene esa potencialidad de ser positivo (siguiendo a Deleuze) o negativo (siguiendo a Baudrillard).

A juegos como los que he presentado en la primera parte de este artículo les corresponde una realidad propia que no solamente es instaurada mediante el simulacro, es decir, mediante su aparición material, sino también reforzada mediante la interactividad. Las dos posturas pueden operar sobre estas imágenes sin contradecirse, pues si bien el factor de la interactividad hace que un intercambio entre lo real y ese doble virtual que se presenta en el videojuego se refuerce y se haga cada vez más una posibilidad real, en lugar de una mera posibilidad del pensamiento, la positividad del simulacro también opera de manera intensificada. En últimas, la interactividad parece sugerir una conexión mayor con ese doble un tanto perverso en el que es posible perderse para siempre, como también una conexión mayor con esa posibilidad de ampliación del horizonte de lo real mediante imágenes que tienen una fuerza expresiva y de pensamiento que lo excede.

Asistimos a una radicalización de las propiedades de las imágenes, a una ratificación de la no-representatividad de la imagen conceptualizada por Deleuze en términos de imagen-tiempo. Solamente que ahora el jugador parece poner en acción ese "doble operativo" intuido por Baudrillard, ya que el jugador no solamente interactúa con las imágenes del videojuego, sino que de cierta forma hace parte de ellas, al punto que a medida que se hace más sofisticada la simulación es más probable que él mismo pueda hacer proliferar los simulacros. La experiencia entonces ya no solo estará mediada por los sentidos que perciben la imagen, sino también por la voluntad de simulación que el jugador pueda instaurar a partir de esas imágenes.

\section{LA IMAGEN DEL PENSAMIENTO}

En la introducción hicimos un primer acercamiento a la relación que puede existir entre las imágenes, los simulacros y el pensamiento en la teoría de Gilles Deleuze. 
Aquí nos centraremos en el caso particular ya no de las imágenes del cine, sino de las imágenes del videojuego: ¿qué tienen estas que decirle al pensamiento? Deleuze encuentra en las imágenes-movimiento la potencialidad de evidenciar de manera privilegiada el pensamiento de una época; para Deleuze es evidente que el pensamiento nunca piensa por sí mismo, sino que solo produce a partir de un campo de posibilidades (Asiaín Álvarez, 2007), campo determinado por la imagen del pensamiento, que no está dada explícitamente en ninguna filosofía, no es ni visible ni enunciable, pero síconfigura el campo de enunciación y de visibilidad del pensamiento y todo lo que lo afecta.

Esta imagen del pensamiento, ese campo de enunciación, sin embargo, está constituido, al menos en lo que respecta al pensamiento occidental, de manera dogmática (Asiaín Álvarez, 2007); esto es, atado a la idea platónica de la representación y fuertemente ligado a la idea del simulacro como la copia degradada y sin valor. Para Deleuze, cuando se crean conceptos filosóficos se establece un plano de inmanencia, plano que es el horizonte infinito sobre el cual los conceptos proliferan y pueblan el plano, que no es un concepto, ni algo pensado ni algo pensable, sino una imagen del pensamiento (Deleuze y Guattari, 1993, p. 41), y dado que la imagen del pensamiento solo conserva lo que el pensamiento puede reivindicar por derecho, lo verdadero solo puede definirse en un 'volverse hacia' o un 'hacia lo que se vuelve el pensamiento' sin conservar ningún concepto de verdad (p. 43), por lo que la única forma de ampliar el plano de inmanencia, la imagen del pensamiento, es precisamente la búsqueda de un siempre nuevo, de un no pensado. Así,los elementos del plano son características diagramáticas, en tanto que los conceptos son características intensivas (Deleuze y Guattari, 1993, pp. 43-44). Este no pensado, este nuevo espectro de lo real está dado, entonces, por la proliferación de la diferencia en las imágenes, proliferación de simulacros que amplían ese espectro de lo real y lo hacen más rico, más complejo.

La imagen dogmática del pensamiento, sin embargo,en tanto remite a un ya pensado, es siempre una imagen representativa, está en referencia a un modelo particular que determina su valor de verdad, un fundamento primero. Esta imagen dogmática se corresponde con elpensamiento platónico, que sigue distinguiendo entre modelo, copia y simulacro, de tal modo que solo puede existir de manera consistente cuando la división modelo-copia se mantiene (Asiaín Álvarez, 2007). Este tipo de imagen se asimila a la idea de simulación en Baudrillard, que se explicaba más arriba; así, existe una reificación de una certeza dada, un ya pensado,que permite mantener las certezas de intercambio, la verdad, la objetividad, etc. Sin embargo, una vez que la 
imagen se ha liberado de esta carga, una vez que los simulacros han proliferado y han vuelto a la superficie, la imagen del pensamiento puede cambiar, ser otra.

Por lo que las imágenes del videojuego, al incluir la interactividad en sus características, se instauran como las imágenes que hacen visible y enunciable la complejidad del mundo de hoy, complejidad que está dada por la potencialidad de abandono a esa realidad virtual que Baudrillard pone de relieve en la constitución de un real virtual que puede efectivamente tomar el lugar de lo real mismo. Esta aparición de una posibilidad real de aniquilación de lo real pone de manifiesto unas complejidades para el estudio ontológico que solo son pensables y enunciables luego de que las imágenes del videojuego han proliferado, que nos hemos apropiado de ellas y que nos han permitido pensar de manera más radical que nunca en esa hiperrealidad, en ese real virtual más real que lo real.

Cuando se interroga por qué la imagen del cine es una imagen-pensamiento, es fácil notar que lo es gracias a que,mediante su presentación directa del tiempo y su superación del movimiento, el cine permite contemplar espacio-temporalidades nuevas, dimensiones no cronológicas del tiempo y su relación con el espacio (Asiaín Álvarez, 2007). En otras palabras, al salir de la representación del espacio-tiempo para pasar a su presentación, la imagen del cine escapa del modelo representativo, hace proliferar sus simulacros como el plano de expresión de una nueva potencia de la imagen-pensamiento. Del mismo modo, la imagen del videojuego, que también hace proliferar sus simulacros, ahora más complejos gracias a su interactividad, abre también nuevos espacios y situaciones como potencias 'simuladas' de la imagenpensamiento.

Por eso, del argumento por comparación hemos pasado a la afirmación de la diferencia de la imagen interactiva propia del video juego. La imagen interactiva no solo construye y presenta los bloques de sensación, sino que precisa del agenciamiento del jugador para que la composición sea completa y efectiva. Eso es posible verlo enunciado en los juegos descritos en este artículo, pues en cada uno de ellos no solamente la participación del jugador es vital para completar la historia, sino que la interactividad planteada hace que sea posible que la historia cambie y se modifique con las decisiones del jugador, que de una u otra forma termina por apropiarse de la historia, por hacerla tan suya como le es posible. De modo que el simulacro del videojuego invita al jugador a sumergirse en su realidad, a vivir esa realidad visual como propia, si bien no definitivamente, sí cada vez de manera más intensa y mejor lograda. El nivel de inmersión e interacción alcanzado gracias a esta 
nueva imagen no solamente permite repensar los límites del simulacro, sino que propone nuevas formas de interacción con la imagen/lo real que están aún por descubrir y desarrollar.

\section{REFERENCIAS}

Asiáin Álvarez, E. (2007). "La imagen del pensamiento en Gilles Deleuze; Tensiones entre cine y filosofía". Observaciones Filosóficas.

Baudrillard, J. (1979). El intercambio simbólico y la muerte.Caracas: Monte Ávila.

Baudrillard, J. (1993). Cultura y simulacro . Barcelona: Kairós.

Baudrillard, J.(2000). El intercambio imposible.Madrid: Cátedra.

Beyond Two Souls.(2013). Dirigido por Davd Cage. Producido por Guillaume de Fondaumiere. Sony Computer Entertainment.

Cárdenas, J. D. (2011). "Entre la imagen y el pensamiento: a proposito del pensamiento de Gilles Deleuze". Universitas Philosophica, n. ${ }^{\circ}$ 57, pp. 241262.

Deleuze, G. (1985a). La imagen-movimiento. Estudios sobre cine 1. Barcelona: Paidós.

Deleuze, G. (1985b). La imagen-tiempo. Estudios sobre cine 2. Barcelona: Paidós.

Deleuze, G. (2005). Lógica del sentido. Barcelona: Paidós.

Deleuze, G. y Guattari, F. (1993). ¿Qué es la filosofia? Barcelona: Anagrama.

Heavy Rain. (2010). Dirigido por David Cage. Producido por Quantic Dream. Sony Computer Entertainment.

Houser, D. y Humphries, R. (2013). Grand Theft Auto V. Dirigido por Sam Houser. Producido por Leslie Benzies y Imran Sarwar. Rockstar Games.

Mega Man.(1997). Producido por Keiji Inafune y Yoshinori Takenaka. Capcom.

Mario Bros.(1983). Dirigido por Shigeru Miyamoto, Satoshi Tajiri y Mitsuharo

Sato. Producido por Nintendo. Nintendo. 
Pac-man. (1980). Dirigido por Toru Iwatani. Producido por Namco. Namco, 1980.

Silent Hill 2.(2001). Dirigido por Masashi Tsuboyama. Producido por Akihiro Imamura. Konami.

SimsCity.(1989). Dirigido por Will Wright. Producido por Maxis. Electronic Arts. 